\title{
On the Role of Spirituality and Religiosity in Type 2 Diabetes Mellitus Management-A Systematic Review
}

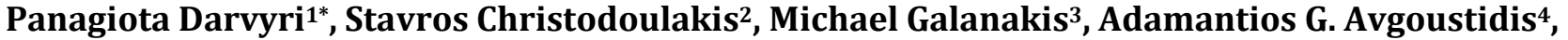 Anastasia Thanopoulou ${ }^{1}$, George P. Chrousos ${ }^{1}$}

\author{
${ }^{1}$ School of Medicine, National and Kapodistrian University of Athens, Athens, Greece \\ ${ }^{2}$ School of Educational Sciences, University of Ioannina, Ioannina, Greece \\ ${ }^{3}$ Panteion University of Social and Political Sciences, Athens, Greece \\ ${ }^{4}$ Pastoral Theology and Psychology, Theological School, National and Kapodistrian University of Athens, Athens, Greece \\ Email: *pandarviri@yahoo.gr
}

How to cite this paper: Darvyri, P. Christodoulakis, S., Galanakis, M., Avgoustidis, A. G., Thanopoulou, A., \& Chrousos, G. P. (2018). On the Role of Spirituality and Religiosity in Type 2 Diabetes Mellitus Management-A Systematic Review. Psychology, 9, 728-744.

https://doi.org/10.4236/psych.2018.94046

Received: March 12, 2018

Accepted: April 20, 2018

Published: April 23, 2018

Copyright (c) 2018 by authors and Scientific Research Publishing Inc. This work is licensed under the Creative Commons Attribution International License (CC BY 4.0).

http://creativecommons.org/licenses/by/4.0/

\begin{abstract}
Background: There has been significant argumentation whether spirituality/religiosity directly affect(s) type 2 diabetes mellitus (T2DM) outcomes and well-being. Objectives: To evaluate the impact of spirituality/religiosity on T2DM management. Data sources: The PubMed database was searched thoroughly for relevant papers. Results: The results show a positive relation between religiosity/spirituality and improved T2DM management. Limitations: The nature of the studies included is mostly qualitative and limited to the PubMed database. Conclusions: Our findings add to the growing evidence that demonstrates the important role of spirituality/religiosity in T2DM management.
\end{abstract}

\section{Keywords}

Religiosity, Spirituality, Type 2 Diabetes Mellitus, Social Support, Holistic Approach

\section{Introduction}

Diabetes mellitus is a heterogeneous group of metabolic diseases characterized by chronic hyperglycemia (ADA, 2009; Koloverou et al., 2014; WHO, 2016) resulting from defects in insulin secretion, insulin action, or both (ADA, 2009) and metabolic disorders, with type 2 diabetes being the most common form (Koloverou et al., 2014). 
Type 2 Diabetes Mellitus (T2DM) is one of the main causes of morbidity and mortality. Obesity (especially visceral obesity), physical inactivity, stress with the chronic activation of the hypothalamic pituitary axis (HPA) can lead to severe metabolic consequences (Koloverou et al., 2014). The American Diabetes Association explains how the chronic hyperglycemia of diabetes is associated with the long-term damage of various organs (e.g. eyes, kidneys, nerves, heart and blood vessels) (ADA, 2009).

Its management is extremely important, as it affects millions of patients and has an increased health care cost (Yazla et al., 2017). T2DM represents $95 \%$ of different types of DM (Spruill, Magwood, Nemeth, \& Williams, 2015) and, regrettably its prevalence is constantly increasing, with a worldwide projection to rise to 592 million in 2035 (IDF Diabetes Atlas Group, 2015).

Depression and diabetes mellitus are major contributors to the global burden of disease and disability measured in Disability Adjusted Life Years (WHO, 2016; Amadi et al., 2016), while the two disorders are frequently comorbidity. Indeed, T2DM is a typical psychosomatic endocrine disorder (Adriaanse \& Snoek, 2006), characterized by a long asymptomatic period (Harris, 1993), and is associated with various degrees of insulin resistance, overweight and obesity (Björntorp, 1998).

Diabetic patients are exposed to chronic stress related to their condition. Generally, everyday issues include anxiety about diabetes' complications and apprehension about food, exercise, and diet (Rubin \& Peyrot, 2001; Reach et al., 2015). Additional distress includes misplaced illness beliefs, lack of knowledge, limited social support and feelings of being overwhelmed by the illness and its requirements (Hermanns, Kulzer, Krichbaum, Kubiak, \& Haak, 2006).

Chronic T2DM-related distress is also associated with increased psychiatric morbidity, such as anxiety and depression, associated with poor glycemic control, non-adherence, and development of T2DM-related complications (Melin, Thunander, Svensson, Landin-Olsson, \& Thulesius, 2013; Ornelas Maia et al., 2013; Palizgir et al., 2013). Thus, the quality of life in these patients demonstrates significant impairment (Porojan, Poantă, \& Dumitraşcu, 2012).

Complementary and alternative medicine (CAM) approaches in the United States and the world are substantial (Eisenberg et al., 1998). People use and value CAM for a variety of reasons. Among some people, religious or cultural beliefs serve as the motivation to use CAM. For others, the motive behind CAM use is the desire to improve health and well-being in conjunction with, rather than as an alternative to conventional medicine. This is frequent because users believe that CAM treats them holistically, with a focus not only on the physical aspects of their ill health, but also on the emotional, mental, social, and spiritual aspects of their illnesses (Weeks \& Strudsholm, 2008).

Spirituality has evolved beyond religious considerations to encompass multidimensional and existential perspectives that are integral to maintaining well-being in the chronically ill (Curlin et al., 2009). Many research studies have 
examined the role of religiosity in the management of diabetes (Ferraro \& Albrecht-Jensen, 1991; Ellison \& Levin, 1998; Koenig, McCulloug, \& Larson, 2001; Williams \& Sternthal, 2007; Krause, 2011; Salmoirago-Blotcher et al., 2011; Krause \& Bastida, 2012; Audulv, 2013; Rivera-Hernandez, 2016). These studies have been performed in a very complex field, granted that there are a number of possible pathways linking disease management (Rivera-Hernandez, 2016) and religiosity affecting health outcomes (Koenig, 2001; Tarakeshwar et al., 2006; Aina, 2006; Agara, 2008; Koenig, 2009).

Religion is an organized (Newlin, Melkus, Tappen, Chyun, \& Koenig, 2008) and common system of beliefs honoring God, which is expressed through external rituals of devotion or worship (Casarez, Engebretson, \& Ostwald, 2010) and promotes the relationship of the individual with God or with a higher power (Newlin, Melkus, Tappen, Chyun, \& Koenig, 2008). Religiousness/religiosity or religious activity represents participation in the observance within a certain religion. Religious faith, on the other hand, is a fundamental system of beliefs, which affects our ideology, values and way of life (How, Ming \& Chin, 2011). Edmonson et al. (2008) indicated that religion is beneficial when it aids in the creation and perseverance of meaning/purpose in one's life (Jafari, Farajzadegan, Loghmani, Majlesi, \& Jafari, 2014).

Recent research has shown the importance of the role of religious leaders in promoting health and well-being in their parishes (Webb, Bopp, \& Fallon, 2013), as they can influence health promotion behaviors and the development of health promotion programs (Rivera-Hernandez, 2015). Such religious leaders with their advice and guidance, may promote healthy lifestyles and proper health care of the members of their congregations (Stansbury, Harley, King, Nelson, \& Speight, 2012; Rivera-Hernandez, 2015), by adopting a holistic approach to health and by linking mental and physical health (Stansbury, Harley, King, Nelson, \& Speight, 2012; Rivera-Hernandez, 2015). They, thus, can help people with chronic illnesses, such as T2DM (Stansbury, Harley, King, Nelson, \& Speight, 2012; Webb, Bopp, \& Fallon, 2013; Rivera-Hernandez, 2015).

Similarly, religion may be a means of dealing with the chronic social and physical disability resulting from type 2 diabetes mellitus (Rivera-Hernandez, 2015).

Not only religion, but also spirituality may play an important role in the experience of life and management of a chronic disease, such as diabetes (Namageyo-Funa, Muilenburg, \& Wilson, 2015). Religious and spiritual strategies for improving diabetes outcomes are faith in God, reading of the Bible or other religious books, prayer and seeking help from religious or spiritual people. Social support by members of the church and their religious beliefs may be associated with aspects of diabetes care (Rivera-Hernandez, 2016; Newlin et al., 2008).

It is very important for healthcare professionals to know the role which religion plays in the lives of diabetic patients and should take into account religious factors in the development of health care programs (Heidari, Rezaei, Sajadi, 
Ajorpaz, \& Koenig, 2017). These may suggest the application of prayer or the use of biblical verses and texts (Namageyo-Funa, Muilenburg, \& Wilson, 2015). Thus, they may support and empower patients in making correct decisions (Heidari, Rezaei, Sajadi, Ajorpaz, \& Koenig, 2017; Rivera-Hernandez, 2016).

These findings are in line with the literature on the use of religion or spirituality and health in African Americans (Chin, Polonsky, Thomas, \& Nerney, 2000; Degazon, 1995; Egede \& Bonadonna, 2003; Mansfield, Mitchell, \& King, 2002; Polzer \& Miles, 2007; Reeves, Adams, Dubbert, Hickson, \& Wyatt, 2012; Samuel-Hodge et al., 2000).

The relations between religiosity and fatalism (Jacobson, 1999), religiosity and domination (Schieman, Nguyen, \& Elliott, 2003) and religiosity and locus of control (Fiori, Brown, Cortina, \& Antonucci, 2006) are quite important for disease outcome. The deterrence of fatalistic feelings and behavior can be a viable strategy to improve the management of diabetes and to accomplish this we need a better understanding of the interaction between religiosity and fatalism (Berardi et al., 2016).

Spirituality can be concisely defined as "related to the ideas of transcendence, meaning, hope and cohesion" (Unantenne, Warren, Canaway, \& Manderson, 2013) and includes personal systems of beliefs referring to a higher power or existence as a dynamic, personal process and experience (Lynch, Hernandez-Tejada, Strom, \& Egede, 2012). It is a highly subjective notion, based on which every person discovers their own existential meaning of life (Unantenne, Warren, Canaway, \& Manderson, 2013). Spirituality is focused on the internal status of our existence and may or may not concern religious structures or traditions (Casarez, Engebretson, \& Ostwald, 2010).

Research has shown that religiosity and/or spirituality are a major determinant of quality of life, while it assists with coping with a chronic disease, promotes optimism and a positive will for life, prevents, depressive symptomatology and allows better coping with stress (Jafari, Farajzadegan, Loghmani, Majlesi, \& Jafari, 2014).

The religious dimension of spirituality includes participation in a series of activities based on faith, official religious activities, personal religious practices, as well as the feeling of spiritual cohesion with nature (Unantenne, Warren, Canaway, \& Manderson, 2013). Spiritual beliefs may depend on whether people believe in a higher power and may include the feeling of having a relationship with such a power. When people do not believe in a higher power, spiritual beliefs are based on the meaning of their life experiences (Cattich \& Knudson-Martin, 2009).

Spirituality is different than religiosity as it refers to the notion of coherence and life purpose and is independent from faith in a certain religion. Religiosity can function as a foundation for spirituality, but at the same time, certain individuals may be spiritual based on their interpretation of experiences, even though they are not followers of a certain religion (Jafari, Farajzadegan, Logh- 
mani, Majlesi, \& Jafari, 2014).

This systematic review has one main goal: to summarize the evidence regarding T2DM outcomes, as they are related to religiosity or spirituality of diabetics.

\section{Methods}

\subsection{Eligibility Criteria-Information Sources}

This study includes papers which aspired to examine the relation between spirituality/religiosity and the outcomes of T2DM, such as glucemic control or depression. No restriction on age, time or type of study was used, except for human participants. We searched the Pubmed database to identify relevant papers, using string key words such as "Spirituality \& Diabetes Type 2", "Spirituality \& HbA1c", "Religiosity \& Diabetes Type 2", "Religiosity \& HbA1c".

\subsection{Study Selection - Data Collection Process - Data Items}

Two reviewers separately assessed the title and abstract of studies for inclusion, and subsequently, the full text of retrieved articles. Subsequent to careful search, studies that did not fulfill the inclusion criteria were not selected. Any disagreement between the authors was resolved after careful examination and consideration.

The number of files initially detected by searching on the PubMed database is 96. Full text articles evaluated for eligibility are 64 . The final number of studies included in the qualitative composition is 26 . In the flow diagram we describe the numerical stages until the final selection of the articles $(n=26)$.

\subsection{Statistical Analyses/Risk of Bias/Quality Assessment}

No statistical analysis was used due to the nature of the studies retrieved. Quality analysis was performed using Newcastle-Ottawa Scale for cohort studies, Qualitative Evaluation Checklist (Michael Quinn Patton available at https://wmich.edu/evaluation/checklists) for Qualitative studies and Strobe Statement for Cross-sectional studies.

\section{Results}

\subsection{Characteristics of the Studies Included in the Current Systematic Review}

Our search included 26 publications (Table 1) out of 96 examined. The flowchart of the study selection process is demonstrated in Figure 1 (Figure according to Prisma statement). More than half of the studies (13 studies) included were qualitative (Samuel-Hodge et al., 2000; Daaleman, Kuckelman Cobb, \& Frey, 2001; Iwasaki et al., 2005; Devlin et al., 2006; Polzer \& Miles, 2007; Cattich \& Knudson-Martin, 2009; Casarez et al., 2010; Unantenne, Warren, Canaway, \& Manderson, 2013; Gupta \& Anandarajah, 2014; Pitaloka \& Hsieh, 2015; Rivera-Hernandez, 2015; Namageyo-Funa, Muilenburg, \& Wilson, 2015; Spruill, Magwood, Nemeth, \& 
Table 1. Characteristics of the studies included in the systematic review.

\begin{tabular}{|c|c|c|c|c|c|c|}
\hline No & Authors-Date & Study type & Participants & \multicolumn{2}{|c|}{ Diadetes Outcome } & Spirituality/Religiosity Questionnaire \\
\hline 1 & $\begin{array}{l}\text { Samuel-Hodge et } \\
\text { al., } 2000 \text {. }\end{array}$ & Qualitative & $\begin{array}{l}70 \text { Southern } \\
\text { African-American } \\
\text { women. }\end{array}$ & Focus group interviews. & & $\begin{array}{l}\text { This shared social context is linked to } \\
\text { disease management such that instead } \\
\text { of educational interventions targeting } \\
\text { the family member with diabetes, they } \\
\text { are directed at relationships within the } \\
\text { family structure. }\end{array}$ \\
\hline 2 & $\begin{array}{l}\text { Daaleman, } \\
\text { Kuckelman } \\
\text { Cobb, \& Frey, } \\
2001 .\end{array}$ & Qualitative & 35 women. & Focus groups interviews. & & $\begin{array}{l}\text { Interrelationships existed among the } \\
\text { categories of patient-reported } \\
\text { spirituality, with spirituality being a } \\
\text { core component of well-being. }\end{array}$ \\
\hline 3 & $\begin{array}{l}\text { Grey, Berry, } \\
\text { Davidson, Galasso, } \\
\text { Gustafson, \& } \\
\text { Melkus, } 2004\end{array}$ & $\begin{array}{l}\text { Prospective } \\
\text { cohort }\end{array}$ & 41 participants. & BMI, HbAlc, CDI & HBQ & $\begin{array}{l}\text { Spirituality ratio increased along with } \\
\text { variables of glycemic control. }\end{array}$ \\
\hline 4 & $\begin{array}{l}\text { Iwasaki et al., } \\
2005 .\end{array}$ & Qualitative & $\begin{array}{l}26 \text { Aboriginal } \\
\text { participants. }\end{array}$ & Focus groups interviews. & & $\begin{array}{l}\text { Spirituality needs to be embedded in } \\
\text { diabetes healthcare practice. }\end{array}$ \\
\hline 5 & $\begin{array}{l}\text { Devlin et al., } \\
2006 .\end{array}$ & Qualitative & $\begin{array}{l}80 \text { middle-aged } \\
\text { native American } \\
\text { tribes sample. }\end{array}$ & Focus groups interviews. & & $\begin{array}{l}\text { Spirituality shaped diabetes } \\
\text { experiences and self-care practices in } \\
\text { all four populations. }\end{array}$ \\
\hline 6 & $\begin{array}{l}\text { Polzer \& Miles, } \\
2007 .\end{array}$ & Qualitative & $\begin{array}{l}22 \text { African } \\
\text { Americans. }\end{array}$ & Minimally structured interviews. & & $\begin{array}{l}\text { This study brings forth an expanded view } \\
\text { of the relationship between God and } \\
\text { participants, as it describes not only the } \\
\text { expectations of God but also those of the } \\
\text { men and women with diabetes as they } \\
\text { worked together in self-management. }\end{array}$ \\
\hline 7 & $\begin{array}{l}\text { Arcury et al., } \\
2007 .\end{array}$ & Cross-sectional & $\begin{array}{l}701 \\
\text { community-dwelli } \\
\text { ng elders. }\end{array}$ & SF-12/CES-D & Private Religious Practices. & $\begin{array}{l}\text { Variation in participation in public } \\
\text { religious practice among rural older } \\
\text { adults is related to physical health and } \\
\text { functional status, along with religiosity, } \\
\text { while private religious practice among } \\
\text { these rural elders is related to personal } \\
\text { characteristics and religiosity. }\end{array}$ \\
\hline 8 & $\begin{array}{l}\text { Newlin et al., } \\
2008 .\end{array}$ & Cross-sectional & 109 Black females. & $\begin{array}{l}\text { HbA1c/DSSS /Diabetes-specific } \\
\text { emotional distress. }\end{array}$ & SWBS-EWB. & $\begin{array}{l}\text { Spirituality has not contributed much } \\
\text { to the model of diabetes control. }\end{array}$ \\
\hline 9 & $\begin{array}{l}\text { Cattich \& } \\
\text { Knudson-Martin } \\
, 2009 .\end{array}$ & Qualitative & $\begin{array}{l}20 \text { heterosexual } \\
\text { couples. }\end{array}$ & Semi-structured interviews. & & $\begin{array}{l}\text { Religious coping helps when there is a } \\
\text { strong bonding between the couple. }\end{array}$ \\
\hline 10 & $\begin{array}{l}\text { Newlin et al., } \\
2010 .\end{array}$ & Cross-sectional & 45 Black females. & CES-D & SWBS & $\begin{array}{l}\text { The existential component of spiritual } \\
\text { well-being demonstrated an } \\
\text { ameliorative relation to mental health. }\end{array}$ \\
\hline 11 & $\begin{array}{l}\text { Casarez et al., } \\
2010 .\end{array}$ & Qualitative & $\begin{array}{l}18 \text { African American } \\
\text { men and women } \\
\text { and be aged } 40 \\
\text { years and older. }\end{array}$ & In-depth interviews. & & $\begin{array}{l}\text { Spirituality provides support for } \\
\text { people dealing with chronic illnesses. }\end{array}$ \\
\hline 12 & How et al., 2011. & Cross-sectional & 212 patients. & $\begin{array}{l}\text { Latest three fasting plasma glucose } \\
\text { (FPG) levels and HbAlc. }\end{array}$ & $\mathrm{BV}$ & $\begin{array}{l}\text { Those with higher religiosity amongst the } \\
\text { Moslem population had significantly } \\
\text { better glycaemic control. Patients who } \\
\text { had church-going religions had better } \\
\text { glycaemic control compared with } \\
\text { those of other religions. }\end{array}$ \\
\hline 13 & $\begin{array}{l}\text { Unantenne et al., } \\
2013 .\end{array}$ & Qualitative & $\begin{array}{l}69 \text { people with } \\
\text { type } 2 \text { diabetes } \\
\text { and/or } \\
\text { cardiovascular } \\
\text { disease. }\end{array}$ & $\begin{array}{l}\text { In-depth interviews with open-ended } \\
\text { questions. }\end{array}$ & & $\begin{array}{l}\text { The resulting emphasis on relationship } \\
\text { to God, to others and to self may have } \\
\text { important health consequences } \\
\text { especially with regard to coping with } \\
\text { chronic illness. }\end{array}$ \\
\hline
\end{tabular}


Continued

\begin{tabular}{|c|c|c|c|c|}
\hline 14 & $\begin{array}{l}\text { Lynch et al., } \\
2012 \text {. }\end{array}$ & Cross-sectional & $\begin{array}{l}201 \text { patients of an } \\
\text { indigent clinic of an } \\
\text { academic medical } \\
\text { center. }\end{array}$ & Depression-CES-D \\
\hline 15 & Jafari et al., 2014. & Cross-sectional & 223 patients. & $\begin{array}{l}\text { Patient Health Questionnaire } \\
\text { (PHQ-2). }\end{array}$ \\
\hline 16 & $\begin{array}{l}\text { Gupta \& } \\
\text { Anandarajah, } \\
2014 .\end{array}$ & Qualitative & $\begin{array}{l}18 \text { patients, all } \\
\text { with type } 2 \\
\text { diabetes mellitus. }\end{array}$ & $\begin{array}{l}\text { Focus-group participants. } \\
\text { Hope questions for spiritual } \\
\text { assessment. }\end{array}$ \\
\hline 17 & $\begin{array}{l}\text { Pitaloka \& Hsieh, } \\
2015 .\end{array}$ & Qualitative & $\begin{array}{l}30 \text { women } \\
\text { with type } 2 \\
\text { diabetes. }\end{array}$ & Focus group participants. \\
\hline 18 & $\begin{array}{l}\text { Rivera-Hernande } \\
\text { Z, } 2015 \text {. }\end{array}$ & Qualitative & $\begin{array}{l}10 \text { male Mexican } \\
\text { religious leaders. }\end{array}$ & $\begin{array}{l}\text { Qualitative semi-structured } \\
\text { key-informant interviews. }\end{array}$ \\
\hline 19 & $\begin{array}{l}\text { Namageyo-Funa, } \\
\text { Muilenburg, \& }\end{array}$ & Qualitative & $\begin{array}{l}12 \text { diabetic Black } \\
\text { men. }\end{array}$ & $\begin{array}{l}\text { In-depth interviews. } \\
\text { Semi-structured interviews. }\end{array}$ \\
\hline
\end{tabular}

DSES

Chronic Illness

Therapy-Spiritual

Well-Being (FACIT-Sp)

Scale.

spi

Significant inverse relationship

between spirituality and depression.

The results of this study showed poor QOL and spiritual well-being and high prevalence of depression in Iranian patients with type 2 diabetes.

In general, participants thought of spirituality more as a source of strength than as a specific motivator for diabetes self-management.

Through the performance of submission, participants demonstrated spirituality and religiosity as essential elements of health.

Religious leaders can support the health promotion of elderly people with diabetes.

Religion and spirituality as a coping strategy for diabetes management. These coping strategies are: prayer and faith in God, the reading of the Bible and the help of religious or spiritual people.

High intrinsic and extrinsic religiosities are associated with better treatment outcome in both diabetes mellitus and depression.

Spirituality is a multidimensional cultural resource and coping strategy for African Americans diabetics.

Religion has a positive correlation with the care, control of diabetes and the behavior of self-care.

A questionnaire that included several variables, such as socio demographic data, health, religion, health care, social support, housing, income, assets and pensions.
23 Amadi et al, Cross-sectional 112 participants with diabetes mellitus.

Religious Orientation Scale Religion is a reliable coping method, (ROS), Religious Orientation which is commonly used by the elderly Scale-Revised (ROS-R) or and depressed women. Positive Intrinsic/ Extrinsic-revised religious coping is more common (I/E-R), Brief Religious among diabetic who are in the low Coping Scale (Brief RCOPE). occupational status.

Self-administered questionnaires assessed diabetes management behaviors and demographic/personal religiosity. characteristics, HbA1c laboratory tests.

25 Yazla et al., 2017. Cohort study 100 patients diagnosed with type 2 diabetes mellitus

\section{Problem Areas in Diabetes Scale} (PAID), Beck Depression Inventor (BDI), State-Trait Anxiety Inventory (STAI), Audit of Diabetes-Dependent Quality of Life (ADDQoL), blood glucose and $\mathrm{HbAlc}$ test results.

26 Heidari, Rezaei, Cross-sectional 154 Iranian Sajadi, Ajorpaz, diabetic patients.
Fatalism Diabetes Scale (DFS), Self-reported

Addressing fatalistic attitudes may be a viable strategy for improving diabetes management, but call for a better understanding of the interplay between religiosity and fatalism in this context

Scale of Forgiveness and Forgiveness by patient himself or others reduced the emotional problems which were experienced related to diabetes by reducing stress levels and could increase QOL.

Private and public religious A relationship between religious practices. practices and self-care in diabetic patients.
Demographic questionnaire,

diabetes self-care activities questionnaires.

Notes: Cross Sectional studies evaluation - Strobe Statement, Qualitative studies evaluation - Qualitative Evaluation Checklist (Michael Quinn Patton available at https://wmich.edu/evaluation/checklists), Cohort studies: Newcastle-Ottawa Scale. 


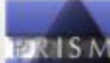

(1)

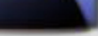

PRISMA 2017 Flow Diagram
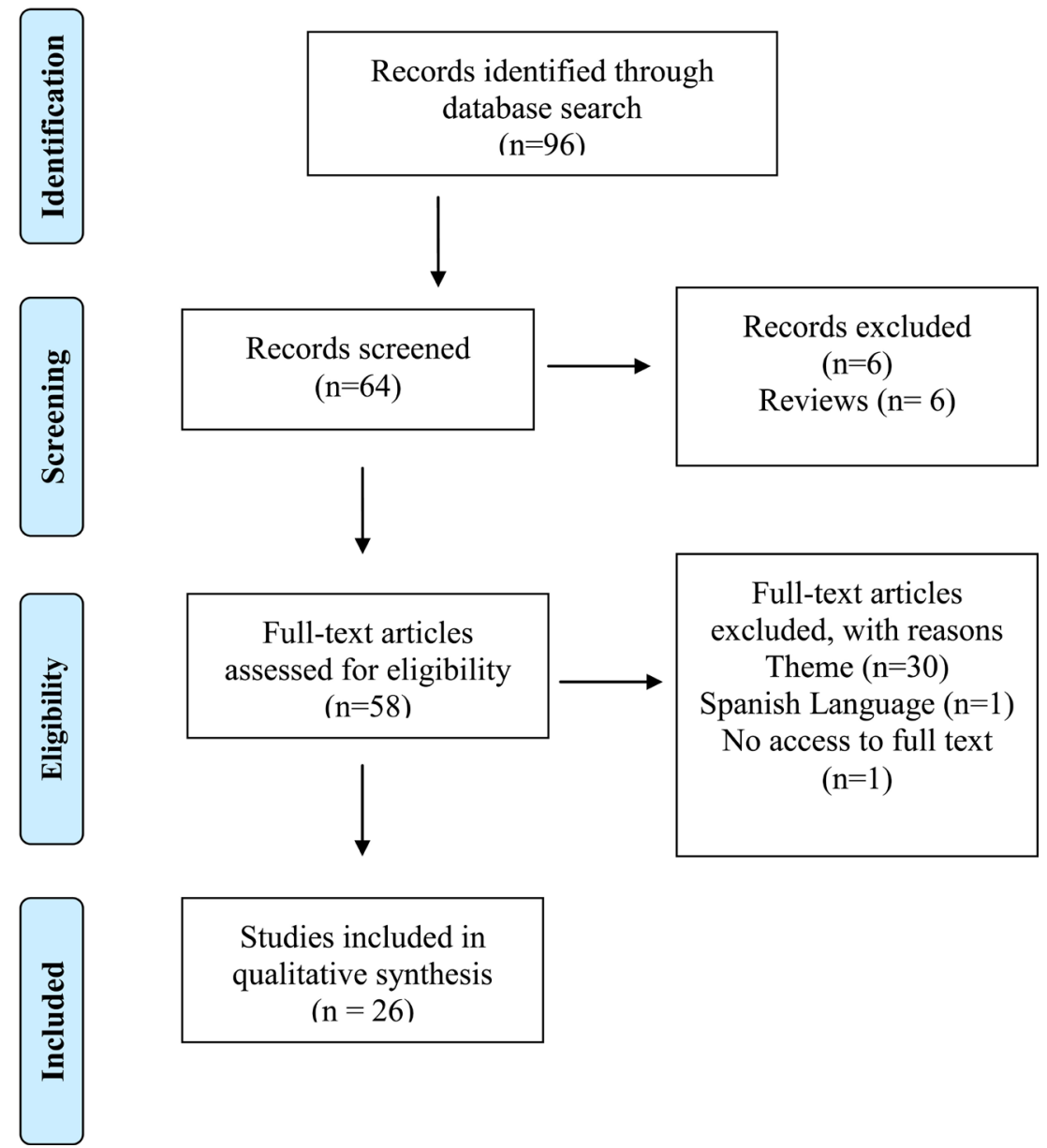

Studies included in qualitative synthesis $(\mathrm{n}=26)$

From: Moher D., Liberati A., Tetzlaff J., Altman D.G., The PRISMA Group (2009). Preferred Reporting Items for Systematic Reviews and Meta-Analyses: The PRISMA Statement. PLoS Med, 6(6): e1000097. Doi: 10.1371/journal.pmed1000097.

Figure 1. Prisma flow diagram of the systematic review.

Williams, 2015). Two of the studies included were cohort studies (Grey et al., 2004), while 11 studies were cross-sectional (Arcury et al., 2007; Newlin et al., 2008; Newlin et al., 2010; How et al., 2011; Lynch et al., 2012; Jafari et al., 2014; Amadi et al., 2015; Rivera-Hernandez, 2016; Amadi et al., 2016; Berardi et al., 2016; Heidari, Rezaei, Sajadi, Ajorpaz, \& Koenig, 2017).

\subsection{Systematic Review Main Findings}

Our findings suggest that women of low socio-economic status exhibit greater rates of religiosity/spirituality and lower rates in depression and, thus, greater control over their diabetes (Lynch, Hernandez-Tejada, Strom, \& Egede, 2012; Kilbourne, Cummings, \& Levine, 2009). 
Religiosity seems to contribute to life in an altruistic approach, which in turn helps with diabetes management, as stress levels are reduced. This was not in agreement with findings of patients who believed that God punished them for their deeds (Unantenne, Warren, Canaway, \& Manderson, 2013).

Spiritual practice may also improve diabetes self-management; with some patients believing that their struggle is helped by God. Attending Church seems to have an ameliorating effect on social bonding and social support, while prayer seems to stabilize the patients' symptoms (Polzer, 2007).

Religious and existential well-being was directly related to mental health of African American women with T2DM, as their existential well-being was dependent on their religiosity/spirituality. Coping in this study seemed to be correlated with social bonding, which was strengthened by their attendance to Church (Newlin et al., 2010). Moreover, it has been shown that religiosity relates to physical well-being (Jafari, Farajzadegan, Loghmani, Majlesi, \& Jafari, 2014).

In another study it was suggested that patients with T2DM consider religiosity/spirituality as a source of hope/strength in order to cope with the disease (Gupta \& Anandarajah, 2014). Also, in another study, positive coping skills and high intrinsic - extrinsic religiosity were associated with better treatment outcome in both diabetes mellitus and depression (Amadi et al., 2016).

Yazla et al. (2017) found that forgiveness by the patient himself or others reduces the emotional problems experienced by diabetics, because there is a reduction in stress levels and, hence, an increase the quality of life (Yazla et al., 2017).

Heidari, Rezaei, Sajadi, Ajorpaz, \& Koenig (2017) found significant positive correlations between religious practices and self-care activities, as well as some religious practices and levels of self-maintenance in patients with type 2 diabetes. Couples in which one of the two suffered from T2DM, demonstrated similar results; the couples' bonding, however, seemed to be of extreme importance, as far as religiosity/spirituality is concerned (Cattich \& Knudson-Martin, 2009).

Another study (Newlin, Melkus, Tappen, Chyun, \& Koenig, 2008) found that spirituality/religiosity is of utmost importance when it comes to glycemic control. Porzer (2007) found that the relationship with God is of a dynamic nature and definitely affects T2DM management. In the same direction the Najmeh et al. study (2014) indicated that inner peace and stamina protects the diabetics from negative emotions and can lead to better management and glycemic control.

When other religious disciplines were examined (Devlin, Roberts, Okaya, \& Xiong, 2006) it was found that participation in religious acts reduced stress levels, which affected directly the glycemic control and there was some hint about the implementation of these techniques in the daily medical practice, in the case of native American patients with type 2 diabetes. Comparable results were those of Iwasaki, Bartlett, \& O'Neil (2005).

In the case of preventive medicine, in prepubertal children, it was found that variables, which measured the prevention outcome, had the same increment 
with religiosity scores (Grey et al., 2004).

Daaleman et al. (2001) tried to explore the patients' perspectives in relation to spiritual beliefs and diabetes' management. They found that religiosity/spirituality was an important factor in glycemic control, but not the only one, as mentality about religion and God seem to play a key role in the diabetes' management approach.

In another qualitative study (Samuel-Hodge et al., 2000), interventions that aimed at self-management improvement should implement spirituality as a general life anti-stress strategy, to address the psychological impact of diabetes. These findings suggested that family-centered and church-based approaches to diabetes care interventions are appropriate.

In a recent study (How, Ming, \& Chin, 2011) it became explicit that religiosity/spirituality is a very important component of glycemic control, especially when the attendance of church was mandatory.

Arcury et al. (2007) found that public religious practice is dependent on physical strength and vice versa, since variation in participation in public religious practice among rural older adults is related to physical health and functional status, along with religiosity, while private religious practice among these rural elders is related to personal characteristics and religiosity.

Last but not least, by examining women's experiences with type 2 diabetes, Pitaloka \& Hsieh (2015) explored how the illness can provide resources to construct meanings of everyday life in Javanese culture. They conducted in-depth interviews with 30 female participants in Central Java, Indonesia, and adopted grounded theory for data analysis. They identified four themes that served as resources for women in Indonesia to 1) ameliorating suffering, 2) resist social control, 3) accept fate, and 4) validate faith. They concluded by noting three unique aspects of Javanese women's illness management. First, through the performance of submission, participants demonstrated spirituality and religiosity as essential elements of health. Second, diabetes empowered individuals in everyday suffering through two divergent processes: embracing submission and resisting control. Finally, diabetes provided opportunities for individuals within a social network to (re)negotiate social responsibilities.

\section{Conclusion}

This systematic review tries in detail to evaluate the impact of spirituality/religiosity on T2DM management. The diversity of the retrieved papers was large. Many of them were of qualitative nature and thus classic meta-analysis was excluded as an option. Studies which were included in the current systematic review examined only the low socio-economic ranks and mostly African-American women.

Limitations obviously result from selection of studies. The nature of the studies included is mostly qualitative and limited to the PubMed database. No statistical analysis was used due to the nature of the studies retrieved.

Our findings suggest that participation in church and spiritual beliefs, which 
imply the belief in the existence of God, seems to have an ameliorating effect on stress levels and, thus, on glycemic control of these patients.

Religiosity and spirituality as sources of emotional support (Samuel-Hodge et al., 2000; Berardi, 2016), are protective against negative feelings, way of life and behavior, as they strengthen type 2 diabetic patients in order to face everyday challenges caused by their disease in a more effective way, and to achieve better glycemic control. Therefore, levels of morbidity and mortality due to type 2 diabetes are lowered through better self-management and self-care (Lynch, Hernandez-Tejada, Strom, \& Egede, 2012).

The relation between spirituality and depression is statistically significant and inverse. According to earlier results, people with high levels of transcendence or spirituality are less likely to experience depression, as spirituality provides them with inner strength and peacefulness, which protects them from negative feelings. Treatment of depressive symptoms in type 2 diabetes patients may thus be facilitated by incorporating spiritual values and beliefs (Lynch, Hernandez-Tejada, Strom, \& Egede, 2012).

Spirituality, as a mediating factor to achieve self-management (Casarez, Engebretson, \& Ostwald, 2010), helps T2DM patients to improve glycemic control (Newlin, Melkus, Tappen, Chyun, \& Koenig, 2008; Jafari, Farajzadegan, Loghmani, Majlesi, \& Jafari, 2014), because it helps them accept their personal responsibility of self-management, as well as it provides them with strength and support to make the right everyday decisions regarding their disease management (Casarez, Engebretson, \& Ostwald, 2010).

According to all of the above, the spirituality role in the management of T2DM is very important, as it helps patients achieve better glycemic control. Future studies should focus on using interventional programs, including a spiritual component, as this practice will be beneficial to both patients and caregivers: for patients, because they will be more focused on their disease's self-management and for caregivers, because they will be more sensitive to their diabetic patients (Casarez, Engebretson, \& Ostwald, 2010).

\section{Acknowledgements}

The author would like to thank Charikleia Stefanaki, Evangelia Karantzi and Artemios Artemiadis for them support in this article.

\section{Conflict of Interest}

All of the authors have no conflict of interest.

\section{References}

Adriaanse, M. C., \& Snoek, F. J. (2006). The Psychological Impact of Screening for Type 2 Diabetes. Diabetes/Metabolism Research and Reviews, 22, 20-25. https://doi.org/10.1002/dmrr.590

Agara, A. J., Makanjuola, A. B., \& Morakinyo, O. (2008). Management of Perceived Mental Health Problems by Spiritual. African Journal of Psychiatry, 11, 113-118. 
https://doi.org/10.4314/ajpsy.v11i2.30262

Aina, O. F. (2006). "Psychotherapy by Environmental Manipulations" and the Observed Symbolic Rites on Prayer Mountains in Nigeria. Mental Health, Religion \& Culture, 9, 1-13. https://doi.org/10.1080/13674670512331322612

Amadi, K. U., Uwakw, R., Odinka, P. C., Ndukuba, A. C., Muomah, C. R., \& Ohaeri J. U. (2016). Religion, Coping and Outcome in Out-Patients with Depression or Diabetes Mellitus. Acta Psychiatrica Scandinavica, 133, 489-496. https://doi.org/10.1111/acps.12537

Amadi, K. U., Uwakwe, R., Ndukuba, A. C., Odinka, P. C., Igwe, M. N., Obayi, N. K., \& Ezeme, M. S. (2016). Relationship between Religiosity, Religious Coping and Socio-Demographic Variables among Out-Patients with Depression or Diabetes Mellitus in Enugu, Nigeria. African Health Sciences, 16, 497-506.

https://doi.org/10.4314/ahs.v16i2.18

American Diabetes Association (2009). Diagnosis and Classification of Diabetes Mellitus. Diabetes Care, 32, S62-S67.

Arcury, T. A., Stafford, J. M., Bell, R. A., Golden, S. L., Snively, B. M., \& Quandt, S. A. (2007). The Association of Health and Functional Status with Private and Public Religious Practice among Rural, Ethnically Diverse, Older Adults with Diabetes. The Journal of Rural Health, 23, 246-253. https://doi.org/10.1111/j.1748-0361.2007.00097.x

Audulv, Å. (2013). The Overtime Development of Chronic Illness Self-Management Patterns: A Longitudinal Qualitative Study. BMC Public Health, 13, 452. https://doi.org/10.1186/1471-2458-13-452

Berardi, V., Bellettiere, J., Nativ, O., Ladislav, S., Hovell, M. F., \& Baron-Epel, O. (2016). Fatalism, Diabetes Management Outcomes, and the Role of Religiosity. Journal of Religion and Health, 55, 602-617. https://doi.org/10.1007/s10943-015-0067-9

Björntorp, P. (1998). The Associations between Obesity, Adipose Tissue Distribution and Disease. Acta Medica Scandinavica. Supplementum, 723, 121-34.

Casarez, R. L., Engebretson, J. C., \& Ostwald, S. K. (2010). Spiritual Practices in Self-Management of Diabetes in African Americans. Holistic Nursing Practice, 24, 227-237. https://doi.org/10.1097/HNP.0b013e3181e903c6

Cattich, J., \& Knudson-Martin, C. (2009). Spirituality and Relationship: A Holistic Analysis of How Couples Cope with Diabetes. Journal of Marital \& Family Therapy, 35, 111-124. https://doi.org/10.1111/j.1752-0606.2008.00105.x

Chin, M. H., Polonsky, T. S., Thomas, V. D., \& Nerney, M. P. (2000). Developing a Conceptual Framework for Understanding Illness and Attitudes in Older, Urban African Americans with Diabetes. The Diabetes Educator, 26, 439-449.

https://doi.org/10.1177/014572170002600311

Curlin, F. A., Rasinski, K. A., Kaptchuk, T. J., Emanuel, E. J., Miller, F. G., \& Tilburt, J. C. (2009). Religion, Clinicians, and the Integration of Complementary and Alternative Medicines. Journal of Alternative and Complementary Medicine, 15, 987-994. https://doi.org/10.1089/acm.2008.0512

Daaleman, T. P., Kuckelman Cobb, A., \& Frey, B. B. (2001). Spirituality and Well-Being: An Exploratory Study of the Patient Perspective. Social Science \& Medicine, 53, 1503-1511. https://doi.org/10.1016/S0277-9536(00)00439-1

Degazon, C. E. (1995). Coping, Diabetes, and the Older African-American. Nursing Outlook, 43, 254-259. https://doi.org/10.1016/S0029-6554(95)80090-5

Devlin, H., Roberts, M., Okaya, A., \& Xiong, Y. M. (2006). Our Lives Were Healthier before: Focus Groups with African American, American Indian, Hispanic/Latino, and 
Hmong People with Diabetes. Health Promotion Practice, 7, 47-55. https://doi.org/10.1177/1524839905275395

Edmondson, D., Park, C. L., Blank, T. O., Fenster, J. R., \& Mills, M. A. (2008). Deconstructing Spiritual Well-Being: Existential Wellbeing and HRQOL in Cancer Survivors. Psycho-Oncology, 17, 161-169. https://doi.org/10.1002/pon.1197

Egede, L. E., \& Bonadonna, R. J. (2003). Diabetes Self-Management in African Americans: An Exploration of the Role of Fatalism. The Diabetes Educator, 29, 105-115. https://doi.org/10.1177/014572170302900115

Eisenberg, D. M., Davis, R. B., Ettner, S. L., Appel, S., Wilkey, S., Van Rompay, M., \& Kessler, R. C. (1998). Trends in Alternative Medicine Use in the United States, 1990-1997: Results of a Follow-Up National Survey. The Journal of the American Medical Association, 280, 1569-1575. https://doi.org/10.1001/jama.280.18.1569

Ellison, C. G., \& Levin, J. S. (1998). The Religion-Health Connection: Evidence, Theory, and Future Directions. Health Education and Behavior, 25, 700-720. https://doi.org/10.1177/109019819802500603

Ferraro, K. F., \& Albrecht-Jensen, C. M. (1991). Does Religion Influence Adult Health? Journal for the Scientific Study of Religion, 30, 193-202. https://doi.org/10.2307/1387213

Fiori, K. L., Brown, E. E., Cortina, K. S., \& Antonucci, T. C. (2006). Locus of Control as a Mediator of the Relationship between Religiosity and Life Satisfaction: Age, Race, and Gender Differences. Mental Health, Religion and Culture, 9, 239-263. https://doi.org/10.1080/13694670600615482

Grey, M., Berry, D., Davidson, M., Galasso, P., Gustafson, E., \& Melkus, G. (2004). Preliminary Testing of a Program to Prevent Type 2 Diabetes among High-Risk Youth. Journal of School Health, 74, 10-15. https://doi.org/10.1111/j.1746-1561.2004.tb06595.x

Gupta, P. S., \& Anandarajah, G. (2014). The Role of Spirituality in Diabetes Self-Management in an Urban, Underserved Population: A Qualitative Exploratory Study. Rhode Island Medical Journal, 97, 31-35.

Harris, M. I. (1993). Undiagnosed NIDDM: Clinical and Public Health Issues. Diabetes Care, 16, 642-652. https://doi.org/10.2337/diacare.16.4.642

Heidari, S., Rezaei, M., Sajadi, M., Ajorpaz, N. M., \& Koenig, H. G. (2017). Religious Practices and Self-Care in Iranian Patients with Type 2 Diabetes. Journal of Religion and Health, 56, 683-696. https://doi.org/10.1007/s10943-016-0320-x

Hermanns, N., Kulzer, B., Krichbaum, M., Kubiak, T., \& Haak, T. (2006). How to Screen for Depression and Emotional Problems in Patients with Diabetes: Comparison of Screening Characteristics of Depression Questionnaires, Measurement of Diabetes-Specific Emotional Problems and Standard Clinical Assessment. Diabetologia, 49, 469-477. https://doi.org/10.1007/s00125-005-0094-2

How, C. B., Ming, K. E., \& Chin, C. Y. (2011). Does Religious Affiliation Influence Glycaemic Control in Primary Care Patients with Type 2 Diabetes Mellitus? Mental Health in Family Medicine, 8, 21-28.

IDF Diabetes Atlas Group (2015). Update of Mortality Attributable to Diabetes for IDF Diabetes Atlas: Estimates for the Year 2013. Diabetes Research and Clinical Practice, 109, 461-465. https://doi.org/10.1016/j.diabres.2015.05.037

Iwasaki, Y., Bartlett, J., \& O’ Neil, J. (2005). Coping with Stress among Aboriginal Women and Men with Diabetes in Winnipeg, Canada. Social Science \& Medicine, 60, 977-988. https://doi.org/10.1016/j.socscimed.2004.06.032

Jacobson, C. (1999). Denominational and Racial and Ethnic Differences in Fatalism. Re- 
view of Religious Research, 41, 9-20. https://doi.org/10.2307/3512424

Jafari, N., Farajzadegan, Z., Loghmani, A., Majlesi, M., \& Jafari, N. (2014). Spiritual Well-Being and Quality of Life of Iranian Adults with Type 2 Diabetes. Evidence-Based Complementary and Alternative Medicine, 2014, Article ID: 619028. https://doi.org/10.1155/2014/619028

Kilbourne, B., Cummings, S. M., \& Levine, R. S. (2009). The Influence of Religiosity on Depression among Low-Income People with Diabetes. Health and Social Work, 34, 137-147. https://doi.org/10.1093/hsw/34.2.137

Koenig, H. G. (2001). Religion and Medicine III: Developing a Theoretical Model. The International Journal of Psychiatry in Medicine, 31, 199-216. https://doi.org/10.2190/2YBG-NL9T-EK7Y-F6A3

Koenig, H. G. (2009). Research on Religion, Spirituality and Mental Health: A Review. The Canadian Journal of Psychiatry, 54, 283-291. https://doi.org/10.1177/070674370905400502

Koenig, H. G., McCullough, M. E., \& Larson, D. B. (2001) Handbook of Religion and Health (pp. 1-628). New York: Oxford University Press.

Koloverou, E., Tentolouris, N., Bakoula, C., Darviri, C., \& Chrousos, G. (2014). Implementation of a Stress Management Program in Outpatients with Type 2 Diabetes Mellitus: A Randomized Controlled Trial. Hormones, 13, 509-518.

Krause, N. (2011). Religion and Health: Making Sense of a Disheveled Literature. Journal of Religion and Health, 50, 20-35. https://doi.org/10.1007/s10943-010-9373-4

Krause, N., \& Bastida, E. (2012). Religion and Health among Older Mexican Americans: Exploring the Influence of Making Mandas. Journal of Religion and Health, 51, 812-824. https://doi.org/10.1007/s10943-010-9389-9

Lynch, C. P., Hernandez-Tejada, M. A., Strom, J. L., \& Egede, L. E. (2012). Association between Spirituality and Depression in Adults with Type 2 Diabetes. The Diabetes Educator, 38, 427-435. https://doi.org/10.1177/0145721712440335

Mansfield, C., Mitchell, J., \& King, D. (2002). The Doctor as God's Mechanic? Beliefs in the Southeastern United States. Social Science and Medicine, 54, 399-409. https://doi.org/10.1016/S0277-9536(01)00038-7

Melin, E. O., Thunander, M., Svensson, R., Landin-Olsson, M., \& Thulesius, H. O. (2013). Depression, Obesity, and Smoking Were Independently Associated with Inadequate Glycemic Control in Patients with Type 1 Diabetes. European Journal of Endocrinology, 168, 861-869. https://doi.org/10.1530/EJE-13-0137

Namageyo-Funa, A., Muilenburg, J., \& Wilson, M. (2015). The Role of Religion and Spirituality in Coping with Type 2 Diabetes: A Qualitative Study among Black Men. Journal of Religion and Health, 54, 242-252. https://doi.org/10.1007/s10943-013-9812-0

Newlin, K., Melkus, G. D., Peyrot, M., Koenig, H. G., Allard, E., \& Chyun, D. (2010). Coping as a Mediator in the Relationships of Spiritual Well-Being to Mental Health in Black Women with Type 2 Diabetes. The International Journal of Psychiatry in Medicine, 40, 439-459. https://doi.org/10.2190/PM.40.4.g

Newlin, K., Melkus, G. D., Tappen, R., Chyun, D., \& Koenig, H. G. (2008). Relationships of Religion and Spirituality to Glycemic Control in Black Women with Type $2 \mathrm{Di}$ abetes. Nursing Research, 57, 331-339.

https://doi.org/10.1097/01.NNR.0000313497.10154.66

Ornelas Maia, A. C., Braga Ade, A., Paes, F., Machado, S., Carta, M. G., Nardi, A. E. et al. (2013). Comorbidity of Depression and Anxiety: Association with Poor Quality of Life in Type 1 and 2 Diabetic Patients. Clinical Practice and Epidemiology in Mental Health, 9, 136-141. https://doi.org/10.2174/1745017901309010136 
Palizgir, M., Bakhtiari, M., \& Esteghamati, A. (2013). Association of Depression and Anxiety with Diabetes Mellitus Type 2 Concerning Some Sociological Factors. Iranian Red Crescent Medical Journal, 15, 644-648. https://doi.org/10.5812/ircmj.12107

Pitaloka, D., \& Hsieh, E. (2015). Health as Submission and Social Responsibilities: Embodied Experiences of Javanese Women with Type 2 Diabetes. Qualitative Health Research, 25, 1155-1165. https://doi.org/10.1177/1049732315577607

Polzer, R. L. (2007). African Americans and Diabetes: Spiritual Role of the Health Care Provider in Self-Management. Research in Nursing \& Health, 30, 164-174. https://doi.org/10.1002/nur.20179

Polzer, R. L., \& Miles, M. S. (2007). Spirituality in African Americans with Diabetes: Self-Management through a Relationship with God. Qualitative Health Research, 17, 176-188. https://doi.org/10.1177/1049732306297750

Porojan, M., Poantă, L., \& Dumitraşcu, D. L. (2012). Assessing Health Related Quality of Life in Diabetic Patients. Romanian Journal of Internal Medicine, 50, 27-31.

Reach, G., Consoli, S. M., Halimi, S., Colas, C., Duclos, M., Fontaine, P. et al. (2015). The Multinational Second Diabetes, Attitudes, Wishes and Needs Study: Results of the French Survey. Patient Preference and Adherence, 9, 289-297. https://doi.org/10.2147/PPA.S68941

Reeves, R. R., Adams, C. E., Dubbert, P. M., Hickson, D. A., \& Wyatt, S. B. (2012). Are Religiosity and Spirituality Associated with Obesity among African Americans in the Southeastern United States (the Jackson Heart Study)? Journal of Religion and Health, 51, 32-48. https://doi.org/10.1007/s10943-011-9552-y

Rivera-Hernandez, M. (2015). The Role of Religious Leaders in Health Promotion for Older Mexicans with Diabetes. Journal of Religion and Health, 54, 303-315.

https://doi.org/10.1007/s10943-014-9829-z

Rivera-Hernandez, M. (2016). Religiosity, Social Support and Care Associated with Health in Older Mexicans with Diabetes. Journal of Religion and Health, 55, 1394-1410. https://doi.org/10.1007/s10943-015-0105-7

Rubin, R. R., \& Peyrot, M. (2001). Psychological Issues and Treatments for People with Diabetes. Journal of Clinical Psychology, 57, 457-478. https://doi.org/10.1002/jclp.1041

Salmoirago-Blotcher, E., Fitchett, G., Ockene, J. K., Schnall, E., Crawford, S., Granek, I. et al. (2011). Religion and Healthy Lifestyle Behaviors among Postmenopausal Women: The Women's Health Initiative. Journal of Behavioral Medicine, 34, 360-371. https://doi.org/10.1007/s10865-011-9322-Z

Samuel-Hodge, C. D., Headen, S. W., Skelly, A. H., Ingram, A. F., Keyserling, T. C., Jackson, E. J., Ammerman, A. S., \& Elasy, T. A. (2000). Influences on Day-to-Day Self-Management of Type 2 Diabetes among African-American Women: Spirituality, the Multi-Caregiver Role, and Other Social Context Factors. Diabetes Care, 23, 928-933.

https://doi.org/10.2337/diacare.23.7.928

Schieman, S., Nguyen, K., \& Elliott, D. (2003). Religiosity, Socioeconomic Status, and the Sense of Mastery. Social Psychology Quarterly, 66, 202-221.

https://doi.org/10.2307/1519822

Spruill, I. D., Magwood, G. S., Nemeth, L. S., \& Williams, T. H. (2015). African Americans' Culturally Specific Approaches to the Management of Diabetes. Global Qualitative Nursing Research, 2, 1-9.

Stansbury, K. L., Harley, D. A., King, L., Nelson, N., \& Speight, G. (2012). African American Clergy: What Are Their Perceptions of Pastoral Care and Pastoral Counseling? Journal of Religion and Health, 51, 961-969. https://doi.org/10.1007/s10943-010-9413-0 
Tarakeshwar, N., Vanderwerker, L. C., Paulk, E., Pearce, M. J., Kasl, S. V., \& Prigerson, H. G. (2006). Religious Coping Is Associated with Quality of Life of Patients with Advanced Cancer. Journal of Palliative Medicine, 9, 646-657.

https://doi.org/10.1089/jpm.2006.9.646

Unantenne, N., Warren, N., Canaway, R., \& Manderson, L. (2013). The Strength to Cope: Spirituality and Faith in Chronic Disease. Journal of Religion and Health, 52, 1147-1161. https://doi.org/10.1007/s10943-011-9554-9

Webb, B., Bopp, M., \& Fallon, E. A. (2013). A Qualitative Study of Faith Leaders' Perceptions of Health and Wellness. Journal of Religion and Health, 52, 235-246. https://doi.org/10.1007/s10943-011-9476-6

Weeks, L. C., \& Strudsholm, T. (2008). A Scoping Review of Research on Complementary and Alternative Medicine (CAM) and the Mass Media: Looking Back, Moving Forward. BMC Complementary and Alternative Medicine, 8, 43.

https://doi.org/10.1186/1472-6882-8-43

Williams, D. R., \& Sternthal, M. J. (2007). Spirituality, Religion and Health: Evidence and Research Directions. Medical Journal of Australia, 186, S47-S50.

World Health Organization (WHO) (2016). Global Report on Diabetes (pp. 1-88). Publications of the World Health Organization.

Yazla, E., Karadere, M. E., Kucukler, F. K., Karsıdag, C., Inanc, L., Kankoc, E., Donertas, M., \& Demir, E. (2017). The Effect of Religious Belief and Forgiveness on Coping with Diabetes. Journal of Religion and Health, 1-10.

https://doi.org/10.1007/s10943-017-0504-Z 


\section{Abbreviations}

$\mathrm{BMI}=$ Body Mass Index

$\mathrm{HBQ}=$ Health Behavior Questionnaire

CDI $=$ Children's Depression Inventory

HbA1c $=$ Hemoglobin A1c

SF-12 $=$ Short-Form 12

CES-D = Center for Epidemiologic Studies Depression Scale

DSSS $=$ Depression and Somatic Symptoms Scale

DSES $=$ Daily Spiritual Experience Subscale

SWBS $=$ Spiritual Well-Being Scale

$\mathrm{EWB}=$ existential well-being

$\mathrm{BV}=$ Beliefs and Values Scale

QOL $=$ Quality Of Life

DFS $=$ Fatalism Diabetes Scale

ROS $=$ Religious Orientation Scale

ROS-R =Religious Orientation Scale-Revised

$\mathrm{I} / \mathrm{E}-\mathrm{R}=$ Intrinsic/Extrinsic Revised

Brief RCOPE $=$ Brief Religious Coping Scale

MAC $=$ Mental Adjustment to Cancer Scale

SDS = Sheehan's Disability Scale

BDI-II = Becks Depression Inventory-II

SFR $=$ Scale of Forgiveness and Religiosity

PAID $=$ Problem Areas in Diabetes Scale

$\mathrm{BDI}=$ Beck Depression Inventory

STAI $=$ State-Trait Anxiety Inventory

ADDQoL $=$ Audit of Diabetes-Dependent Quality of Life 